\title{
Effects of ultrasonic thawing on the physicochemical properties of frozen pork
}

\author{
Jinse Kim ${ }^{1}$, Seok Ho Park ${ }^{1}$, Dong Soo Choi ${ }^{1}$, Seung Ryul Choi ${ }^{1}$, Yong Hoon Kim ${ }^{1}$, \\ Soo Jang Lee ${ }^{1}$, Chun Wan Park ${ }^{1}$, Gui Jeung Han ${ }^{2}$, Jong Woo Park ${ }^{1 *}$ \\ ${ }^{1}$ Department of Agricultural Engineering, National Institute of Agricultural Sciences, RDA, Jeonju 54875, Korea \\ ${ }^{2}$ Department of Agro-food Resource, National Institute of Agricultural Sciences, RDA, Jeonju 54875, Korea \\ ${ }^{3}$ Department of Biosystem Machinery Engineering, College of Agricultural and Life Science, Chungnam National University, \\ Daejeon 34134, Korea
}

\section{주파수에 따른 초음파 해동처리가 냉동 돈육의 이화학적 특성에 미치는 효과}

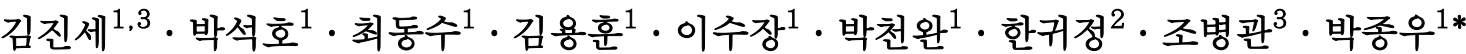 \\ ${ }^{1}$ 농촌진흥청 국립농업과학원 농업공학부, ${ }^{2}$ 농촌진흥청 국립농업과학원 농식품자원부, \\ ${ }^{3}$ 충남대학교 바이오시스템공학과
}

\begin{abstract}
This study was carried out to investigate the effects of ultrasonic thawing on physicochemical characteristics of frozen pork sirloin. To determine the velocity of an ultrasonic thawing machine, $-80^{\circ} \mathrm{C}$ frozen pork sirloins were thawed using 132,580 , and $1,000 \mathrm{kHz}$ ultrasonic thawing machines, and the physicochemical properties of pork sirloin thawed with $15^{\circ} \mathrm{C}$ tap water and those using the ultrasonic thawing machines were compared. As a result, thawing speed by ultrasonic thawing was three times faster than that of tap water, but drip weight loss rate is increased by about $5 \%$ during ultrasonic thawing compared to that during thawing in tap water. However, biochemical properties, such as $\mathbf{p H}$, volatile basic nitrogen, thiobarbituric acid, and total aerobic bacteria, were not improved by ultrasonic thawing. Hunter values, such as total color change and redness, improved slightly after $580 \mathrm{kHz}$ ultrasonic thawing. The hardness and chewiness of the pork sirloin decreased significantly after $580 \mathrm{kHz}$ ultrasonic thawing; however, springiness was not changed. These results indicate that ultrasonic thawing is faster than thawing in tap water, but the physicochemical characteristics of frozen pork sirloin was not significantly improve by ultrasonic sound.
\end{abstract}

Key words : ultrasonic thawing, frozen meat, physicochemical characteristics

\section{서 론}

경제발달에 따른 소득증가와 식습관의 변화로 인해 육류 소비가 지속적인 증가추세에 있으며 돼지, 소, 닭고기 및 이를 이용한 가공 식품이 주를 이룬다. 그중 국내 소비량이

*Corresponding author. E-mail : jwpark0824@chosun.kr Phone : 82-63-238-412, Fax : 82-63-238-4105

Received 13 December 2016; Revised 2 February 2017; Accepted 6 February 2017.

Copyright (c) The Korean Society of Food Preservation. All rights reserved.
가장 많은 축종은 돼지로서, 국내에서는 돈육를 크게 목심, 앞다리, 등심, 안심, 갈비살, 삼겹살 및 뒷다리 7개 부위로 구분되며, 소비자는 목살과 삼겹살을 선호하는 반면 저지 방 부위인 등심과 뒷다리는 선호하지 않기 때문에 소비량이 많지 않다. 하지만 저지방 부위가 전체 도체 중 차지하는 비중은 뒷다리 $30 \%$ 와 등심 $12 \%$ 로 도체 비중의 $42 \%$ 를 차지 하기 때문에 생산량이 많아 수급조절을 위해 장기저장을 필요로 하게 된다 $(1,2)$.

육류의 저장에 있어 냉동은 미생물 성장 및 화학반응을 둔화시킴으로써 냉장 및 건조저장에 비하여 저장기간을 연장할 수 있다고 알려져 있다(3). 이와 같이 냉동저장의 
장점이 존재함에도 불고하고 동결방법, 저장기간 및 해동 에 대한 관리가 부족하면 조직감의 변화, 변색, 드립 발생, 지방 및 단백질의 변질이 발생된다(4). 이에 따라 냉동 및 저장 중 발생하는 품질 회손을 막기 위하여 급속냉동을 이용하여 동결 중 빙결정의 성장을 막고 미세 빙결정을 생성하고, $-20^{\circ} \mathrm{C}$ 이하에서의 균온 저장을 통하여 저장 중 빙결정 성장을 억제함으로써 식품의 조직손상을 최소화하 여 품질 및 형태 유지를 가능하게 한다(5). 하지만 냉동식품 은 일반적으로 해동과정이 필요하며, 이러한 해동은 동결 속도에 비하여 느리게 진행되기 때문에 미생물 성장 및 수분손실과 같은 품질 회손을 피하기 위하여 가능한 낮은 온도에서 신속하게 이루어져야 한다(6). 하지만 일반적으 로 사용되는 상온 해동, $4^{\circ} \mathrm{C}$ 냉장해동 및 유수 해동에서는 열전도율이 낮아 해동시간이 길어지거나 미생물의 성장 및 드립 발생에 의한 품질저하가 나타나게 된다. 이러한 문제를 해결하기 위하여 급속해동에 대한 관심이 높아지면 서 마이크로파 $(7,8)$, 초고압 $(6,9)$, 초음파 $(10,11)$ 및 라디오 파를 이용한 해동기술(12)이 연구되고 있고, 마이크로파를 이용한 전자레인지 정도만 실용화되어 보급된 상태이며, 라디오파를 이용한 해동기는 제품화 단계에 접어들었다. 하지만 초음파를 이용한 급속해동 기술에 대한 연구결과는 미미한 상태이다.

초음파 $(>16 \mathrm{kHz})$ 는 파장 대역에 따라 비파괴범위 $100-1,000 \mathrm{kHz}$ 와 저주파 초음파 16-100 kHz 두 가지 계열로 구분할 수 있으며, 식품산업에서 식품의 가공 및 보존을 위한 초음파의 이용이 지속적으로 증가하고 있다(13). 일반 적으로 식품산업에서 비파괴범위의 저출력 초음파는 비파 괴 검사, 공정 제어, 품질 평가를 위한 분석 도구로 사용되는 반면, 저주파 초음파는 아직까지 흔히 사용되고 있지는 않
지만 전통적인 식품산업 공정에 적용할 경우 처리효율 증가 가 기대됨에 따라 초음파를 다양한 방식으로 이용하고자 하는 연구가 주목받고 있다(14).

따라서, 본 연구에서는 비파괴 범위의 파장대역인 132 , 580 및 $1,000 \mathrm{kHz}$ 의 접촉식 초음파 해동기를 이용하여 냉동 돈육 등심의 해동을 수행하고 관행방법을 이용하여 해동된 돈육과의 품질비교를 통하여 초음파 해동기의 실용화 가능 성에 대한 고찰을 수행하고자 하였다.

\section{재료 및 방법}

\section{실험재료}

본 연구에 사용된 돈육은 계룡 축협 도축장에서 도축 후 진공 포장된 등심을 직접 구입하여 두께 $1 \mathrm{~cm}$ 에 지름 $10 \mathrm{~cm}$ 가량의 원형으로 절단한 후 중심부에 온도 센서를 삽입하고 $-80^{\circ} \mathrm{C}$ 에서 동결 후 각각의 해동방법을 이용하여 해동하였다.

\section{초음파 해동장치 구성}

초음파를 이용한 해동을 위하여 132,580 및 $1,000 \mathrm{kHz}$ 의 공진 주파수를 가지는 진동자를 이용하여 각 주파수 별 접촉식 해동기를 설계하고 Ul-tech(Uiwang, Korea)을 통하 여 제작하였다. 초음파 주파수 발생장치의 최대 출력은 600 $\mathrm{W}$ 로 다이얼을 이용하여 원하는 출력을 설정할 수 있도록 제작 되었다. 제작된 초음파 해동장치의 구성을 Fig. 1에 나타내었다. 초음파 해동판은 접촉면적을 넓히기 위하여 표면적 $240 \mathrm{~cm}^{2}$ 의 상-하판 형태로 해동하고자 하는 대상물 의 크기에 따라 높이를 자유롭게 조절할 수 있도록 제작하

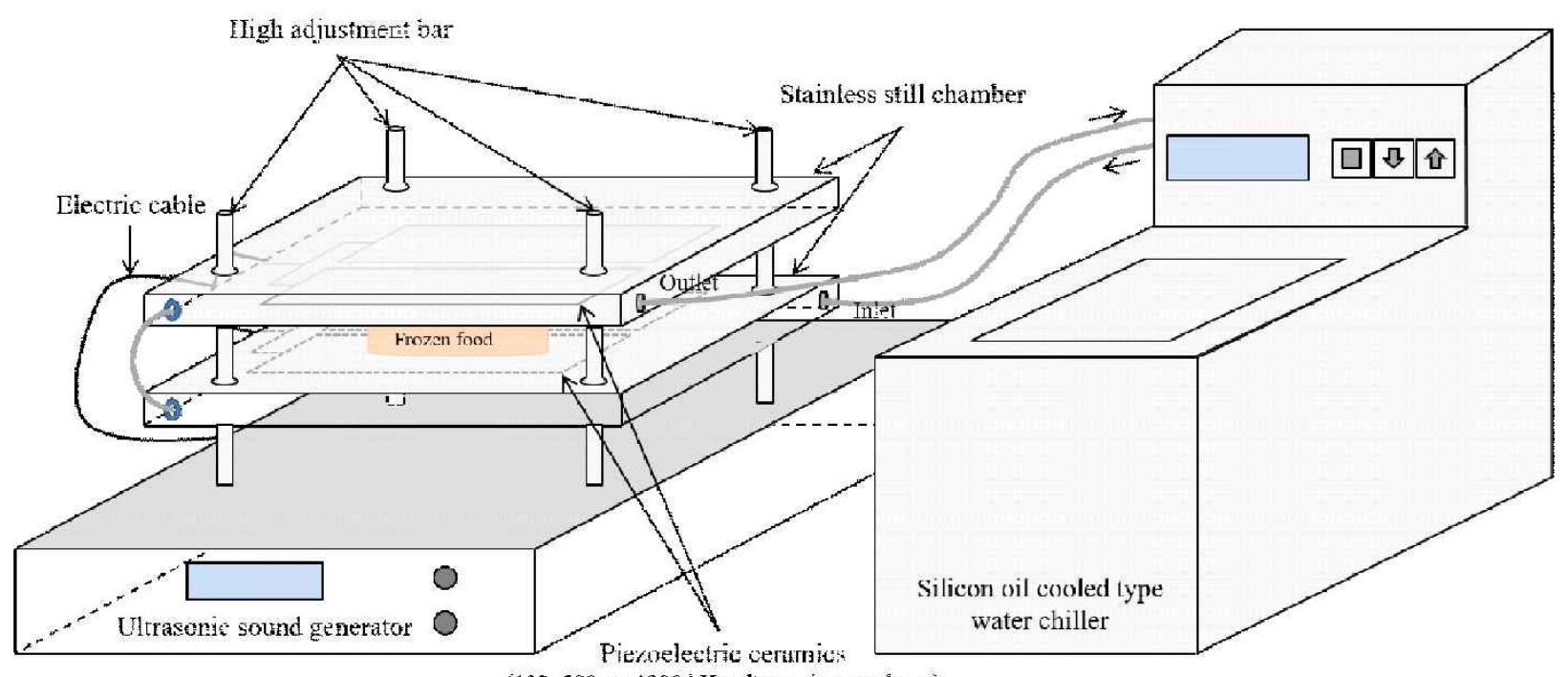

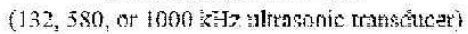

Fig. 1. Schematic diagram of the ultrasonic thawing system. System includes a metallic tank composed of a pair of ultrasonic transducer $(132,580$, and $1,000 \mathrm{kHz}), 600 \mathrm{~W}$ ultrasonic generator, and a cooling units. 
였다. 해동기의 스테인레스 챔버 내부에 각 주파수의 초음 파 진동자를 2 개씩 위치시키고, 해동판으로 제작된 챔버 내부에 $5^{\circ} \mathrm{C}$ 로 냉각된 $1.5 \mathrm{~L}$ 가량의 실리콘 오일을 순환시켜 햐동판의 가열 및 과열에 의한 진동자 파손을 방지하였다.

\section{해동방법}

제작된 132,580 , 및 $1,000 \mathrm{kHz}$ 초음파(ultrasonic frequency, $\mathrm{UF}$ 해동기의 진동자 및 냉동육의 가열을 막기 위하여 수냉 식 냉각기를 장착하여 해동기의 내부 및 표면을 $5^{\circ} \mathrm{C}$ 로 유지 시킨 상태에서 $300 \mathrm{~W}$ 의 출력으로 해동을 수행하였다. 각 주파수에 따른 냉동육의 해동속도 및 품질특성을 $15^{\circ} \mathrm{C}$ 냉수 해동과 초음파를 작동시키지 않고 표면 온도를 $15^{\circ} \mathrm{C}$ 로 조절 한 접촉식 해동과 비교 분석하였다.

\section{해동감량}

냉동 전 정형된 등심육 표면의 수분을 제거 후 질량을 측정하고 개별 포장하여 냉동하였다. 냉동육을 각 해동 방 법에 따라 해동하고 포장을 제거한 상태에서 표면을 수분을 완전히 제거한 후 질량을 측정하여 질량의 변화를 백분율로 나타내었다.

Thawing loss $(\%)=\left\{\left(\mathrm{W}_{1}-\mathrm{W}_{2}\right) / \mathrm{W}_{1}\right\} \times 100$

$\left(\mathrm{W}_{1}\right.$ : 냉동 전 중량, $\mathrm{W}_{2}$ : 냉 해동 후 중량)

\section{지방산패도}

지방산패도는 Witte(15)에 따라 thiobarbituric acid value(TBA)를 측정하였다. 등심 $5 \mathrm{~g}$ 에 $15 \mathrm{~mL}$ 의 증류수를 넣고 $50 \mathrm{uL}$ 의 $7.2 \%$ butylated hydroxylanisole(Sigma Co., St. Louis, Mo, USA)가 후 분쇄기(HMF-1000, Hanil, Seoul, Korea)를 이용하여 60 초간 분쇄하여 $2 \mathrm{~mL}$ 의 균질액을 취하 여 $15 \%$ TCA(Junsei chem. Co., Ltd., Tokyo, Japan)에 용해된 $20 \mathrm{mM}$ TBA(Sigma Co.) 용액 $4 \mathrm{~mL}$ 을 첨가하여 혼합 후 $95^{\circ} \mathrm{C}$ 에서 30 분간 가열 후 상온에서 냉각시켰다. 반응이 끝 난 혼합액을 원심분리기(CF-10, Daihan Sci. Co., Ltd., Wonju, Korea)를 이용하여 $13,000 \mathrm{rpm}$ 에서 10 분간 원심분 리 후 상층액을 취하여 분광광도계(OPRON-3000, Hanson Tech. Co., Ltd., Seoul, Korea)를 이용하여 $530 \mathrm{~nm}$ 에서 흡광 도를 측정하고, 아래 계산식에 따라 TBA값으로 하였다.

$\mathrm{TBA}(\mathrm{mg}$ malonaldehyde $/ \mathrm{kg}$ sample $)=$ Absorbance $\times 5.2$

\section{단백질변패도}

단백질의 변패도는 미량확산법을 이용하여 휘발성염기 질소(volatile basic nitrogen, $\mathrm{VBN}$ )를 측정하였다. 등심육 $20 \mathrm{~g}$ 과 증류수 $160 \mathrm{~mL}$ 을 넣고 분쇄기를 이용하여 균질화 한 후 $3,000 \mathrm{rpm}$ 에서 10 분간 원심 분리하여 상층액 만을 취하였다. 상층액 $1 \mathrm{~mL}$ 과 $50 \% \mathrm{~K}_{2} \mathrm{CO}_{3}$ (Junsei chem. Co.,
Ltd., Tokyo, Japan) 용액 $1 \mathrm{~mL}$ 을 혼합한 후 Conway 미량확 산기 외실에 넣고, 내실에는 지시약을 포함하는 $10 \%$ $\mathrm{H}_{3} \mathrm{BO}_{3}$ (Junsei chem. Co., Ltd., Tokyo, Japan)용액 $1 \mathrm{~mL}$ 을 내실에 넣고 밀폐시켰다. 이후 $37^{\circ} \mathrm{C}$ 에서 2 시간 정치하고, $0.02 \mathrm{~N} \mathrm{H}_{2} \mathrm{SO}_{4}$ (Duksan Co., Ansan, Korea)를 이용하여 내실 의 $\mathrm{H}_{3} \mathrm{BO}_{3}$ 를 적정하였다. 공실험은 외실에 $50 \% \mathrm{~K}_{2} \mathrm{CO}_{3}$ 를 가하지 않은 것에 대한 적정값으로 하였다.

$$
\begin{aligned}
& \mathrm{VBN}(\mathrm{mg} \%)=\{0.14 \times(\mathrm{b}-\mathrm{a})\} / \mathrm{W} \times 100 \times \mathrm{d} \\
& \mathrm{a}: \text { 시료의 } 0.02 \mathrm{~N} \mathrm{H}_{2} \mathrm{SO}_{4} \text { 적정량 }(\mathrm{mL}) \\
& \mathrm{b}: \text { 공시험 } 0.02 \mathrm{~N} \mathrm{H}_{2} \mathrm{SO}_{4} \text { 적정량 }(\mathrm{mL}) \\
& \mathrm{W}: \text { 시료 채취량 }(\mathrm{g}) \\
& \mathrm{d}: \text { 희석배수 }
\end{aligned}
$$

\section{미생물 및 $\mathrm{pH}$}

총균수 및 $\mathrm{pH}$ 변화를 측정하기 위하여 등심 $20 \mathrm{~g}$ 을 완전 히 분쇄한 후 증류수 $50 \mathrm{~mL}$ 을 가하여 균질화 하였다. $\mathrm{pH}$ 측정기(Orion Star A221, Thermo scientific, Beverly, MA, USA)를 이용하여 냉 해동에 따른 균질액의 $\mathrm{pH}$ 변화를 측정 하고, 총균수 측정을 위하여 각 균질액을 peptone수에 희석 하고 준비된 표준한천배지(plate counting agar, Difco, Sparks, $\mathrm{MD}, \mathrm{USA})$ 에 도말하고 $35^{\circ} \mathrm{C}$ 에서 72 시간 배양하였 다. 이후 평판 당 30-300개의 집락이 형성된 평판을 선정하 여 총 집락수를 산정하고, 등심 $\mathrm{g}$ 당 colony forming $\operatorname{unit}(\mathrm{CFU} / \mathrm{g})$ 으로 나타내었다.

\section{색도변화}

해동에 따른 돈육 등심의 색도 변화는 색차계(CR-400, Konica Minolta, Tokyo, Japan)을 이용하여 표준 백색판 $(\mathrm{L}=96.75, \mathrm{a}=0.03, \mathrm{~b}=1.76)$ 으로 보정한 후 동일 실험군에서 냉동 전과 해동 후에 6회 이상 반복 측정하였다. 색도는 명도(lightness)를 나타내는 L 값, 적색도(redness)를 나타내 는 $\mathrm{a}$ 값과 황색도(yellowness)를 나타내는 $\mathrm{b}$ 값으로 나타내 었고, 냉 해동 전후의 색도 변화 비교를 위해 색차값 $(\Delta \mathrm{E})$ 를 산출하였다.

Total color difference $\left.(\Delta \mathrm{E})=\quad-L_{2}\right)^{2}+\left(a_{1}-a_{2}\right)^{2}+\left(b_{1}-b_{2}\right)^{2}$ $\mathrm{L}_{1}$ : 냉동전 등심의 명도, $\mathrm{L}_{2}$ : 해동후 등심의 명도, $\mathrm{a}_{1}$ : 냉동전 등심의 적색도, $\mathrm{a}_{2}$ : 해동후 등심의 적색도, $\mathrm{b}_{1}$ : 냉동전 등심의 황색도, $\mathrm{b}_{2}$ : 해동후 등심의 황색도

\section{물성변화}

해동된 등심육을 $1 \mathrm{~cm} \times 1 \mathrm{~cm} \times 1 \mathrm{~cm}$ 의 크기로 성형한 후 경도계(TA-XT2, Stable Micro System Ltd., Godalming, UK) 에 standard compression platen probe(SMS P/100; $100 \mathrm{~mm}$ dia., $10 \mathrm{~mm}$ long)를 장착하고 $1.5 \mathrm{~mm} / \mathrm{sec}$ 의 속도로 변형율 (strain) $30 \%$ 까지의 texture profile analysis(TPA) 실험을 수 
행하였다. 분석 항목은 Bourne(16)에 따라 응집성 (cohesiveness), 탄력성(springiness), 뭉침성(gumminess) 및 저작성(chewiness)에 대하여 냉동 전 및 해동 후 값에 대하 여 비교하였다(16).

\section{Cohesiveness $=$ area2/area 1}

Springiness=peak 2 time/peak 1 time

Gumminess $=$ peak $\max \times$ cohesiveness

Chewiness $=$ gumminess $\times$ springiness

\section{통계처리}

통계분석은 IBM SPSS Statistics program(Version 22, SPSS Inc., Chicago, IL, USA)을 사용하였으며 모든 실험 결과들은 3 회 반복 측정한 평균값을 이용하여 일원배치 분산분석(One-way ANOVA)을 실시하였고, 시료 간의 유 의적 차이가 있으면 Duncan's multiple range test를 통해 사후 검증하였다 $(\mathrm{p}<0.05)$.

\section{결과 및 고찰}

\section{해동온도 변화}

냉동육의 초음파 출력에 따른 해동 곡선을 Fig. 2에 나타 내었다. 각 냉동육의 내부 온도가 $-20^{\circ} \mathrm{C}$ 에서 상변화가 종료 되는 시점인 $0^{\circ} \mathrm{C}$ 까지 소요되는 시간은 일반적으로 많이 이용되는 $20^{\circ} \mathrm{C}$ 상온에서 101 분, $15^{\circ} \mathrm{C}$ 유수해동의 경우 26 분 이 소요되었으며, 초음파를 가하지 않은 $15^{\circ} \mathrm{C}$ 접촉식 해동 에서 23 분, 출력을 $300 \mathrm{~W}$ 로 조절한 $132 \mathrm{kHz}$ 초음파를 가하 였을 때 14 분, $580 \mathrm{kHz}$ 초음파 해동에서는 9분, $1,000 \mathrm{kHz}$ 해동에서 6 분이 소요되었다. 제작한 초음파 해동기의 동일 출력에서 해동속도는 주파수에 비례하여 증가하는 경향을

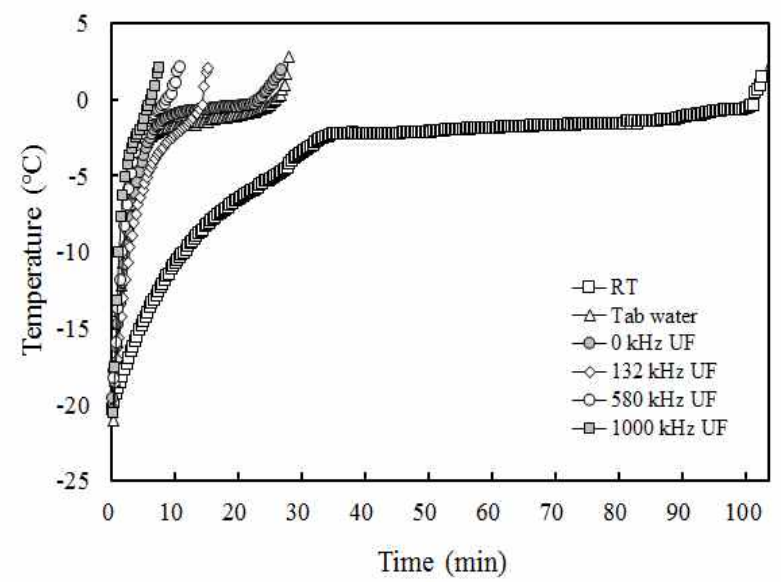

Fig. 2. Temperature change of frozen meats during thawing process under ultrasonic thawing systems.

Data were expressed as mean values $(n=3)$.
나타냈으나, $1,000 \mathrm{kHz}$ 에서는 해동기의 발열 높게 나타나 해동이 진행되는 6 분 동안 $18^{\circ} \mathrm{C}$ 까지 증가하여 냉동육의 표면의 온도가 상승하였다. 이는 Miles 등(10)의 연구에서 높은 주파수의 초음파에서 표면가열 현상이 나타나며, 500 $\mathrm{kHz}$ 대역의 주파수가 표면가열이 가장 적고 침투 깊이가 깊어 원할 한 해동을 진행할 수 있다는 연구와 일치하는 것으로 해동속도 및 표면가열을 고려했을 때 $580 \mathrm{kHz}$ 를 이용한 초음파 해동기의 이용이 가장 적절할 것으로 판단된 다.

해동감량 및 $\mathrm{pH}$ 변화

초음파 해동기의 주파수에 따른 동결육의 해동감량을 Table 1에 나타내었다. 해동감량은 유수해동에서 $1.8 \%$ 가 량을 나타낸 반면 접촉식 해동에서는 $2.3 \%$ 이상으로 유의적 으로 높게 나타났다. 일반적으로 해동감량은 냉동속도나 저장에 의하여 세포손상 정도에 따라 좌우되지만(17), 해동 중에도 단백질 변성에 의하여 보수력 감소에 따른 드립 발생에 의하여 해동감량이 일어난다(18). 이와 같이 해동기 를 이용한 접촉식 해동에서는 냉동시 손상된 세포 및 조직 에서 해동 직후 해동기의 무게에 의한 압착에 따라 드립 발생이 증가된 것으로, 해동종료 시점을 성형 및 가공이 가능한 $-5-0^{\circ} \mathrm{C}$ 로 설정할 경우 드립으로 인한 해동감량을 최소화 할 수 있을 것으로 판단된다.

초음파 주파수에 따른 동결육의 $\mathrm{pH}$ 변화를 Table 1에 나타내었다. 육류의 근섬유내 글리코겐 함량에 의하여 결 정되는 $\mathrm{pH}$ 는 일반적으로 신선육에서 $\mathrm{pH}$ 5.5-5.6를 나타낸 다(20). Farouk 등(21)에 따르면 해동시 세포내 용질의 농도 변화 및 드립 발생에 따라 보수력이 감소한 해동육은 $\mathrm{pH}$ 가 증가한다고 밝히고 있다. 본 연구에서는 신선육이 $\mathrm{pH} 5.6$ 가량을 나타내었으며, 낮은 초음파 주파수 해동에서는 유 의적 차이를 나타내지 않았으나 $1,000 \mathrm{kHz}$ 해동에서는 $\mathrm{pH}$ 5.8 까지 소폭 증가하였다. 이는 해동곡선(Fig. 2)에는 나타 나지 않았지만 $1,000 \mathrm{kHz}$ 해동에서 나타난 표면가열에 의 한 온도상승에 의하여 근섬유의 손상이 가중되어 해동육의 $\mathrm{pH}$ 상승이 나타난 것으로 판단된다.

\section{VBN, TBA 및 미생물 변화}

초음파 해동에 따른 동결육의 VBN 및 TBA 값 변화를 Table. 1 에 나타내었다. 사용된 신선육의 초기 VBN가는 $5.21 \mathrm{mg} \%$ 로 나타났으며, 냉동 및 해동에 의하여 소폭 증가 를 나타냈으나 유의적인 차이를 나타내지 않았다. TBA가 역시 신선육에서 $0.17 \mathrm{MDA} \mathrm{mg} / \mathrm{kg}$ 을 나타냈으나 해동육에 서 소폭 증가 하였지만 유의적인 차이는 나타나지 않았다. 신선육의 $\mathrm{TBA}$ 값은 $0.2 \mathrm{MDA} \mathrm{mg} / \mathrm{kg}$ 수준이며 냉장저장, 가열 및 냉·해동을 거치면서 $\mathrm{VBN}$ 및 TBA 값의 증가가 나타나는 것으로 알려져 있다(21). Choi 등(22)은 부패수준 돈육의 $\mathrm{VBN}$ 값을 $30 \mathrm{mg} \%$ 로 밝히고 있으며, Turner 등(23) 
은 식용 가능한 돈육의 $\mathrm{TBA}$ 값을 $0.46 \mathrm{MDA} \mathrm{mg} / \mathrm{kg}$ 로 규정 하고 있기 때문에 본 연구에서 사용된 해동방법은 단백질 변패에 의한 휘발성 염기질소의 증가나 지방산의 산패에 따른 돈육의 품질에 큰 영향을 미치지 않는 것으로 판단된 다.

초음파 해동에서 주파수에 따른 동결육의 미생물 변화를 Table 1에 나타내었다. 신선육과 해동육 사이에서 일반 세 균수는 유의적인 차이를 보이지 않았지만, $1,000 \mathrm{kHz}$ 의 초 음파를 이용한 해동에서는 소폭 감소하는 경향을 나타내었 으나 그 차이가 미약하였다. Park 등(8)에 따르면 해동 중 온도상승과 느린 해동은 미생물의 오염 및 성장을 증가시킬 수 있다고 밝히고 있다. 하지만 본 연구에서는 30 분 이내에 거의 모든 해동이 이루어졌으며, 개별포장 상태에서 해동 이 진행되어 오염 요소가 최소화되어 증가 경향은 나타나지 안았으며, 오히려 $1,000 \mathrm{kHz}$ 초음파 해동에서는 Ockermann 등(24)이 밝힌 마이크로파에 의한 미생물 세포파괴와 유사 하게 초음파에 의하여 일부 미생물 세포의 파괴가 일어나 총 세균수가 감소한 것으로 판단된다.
Table 2에 나타내었다. 육색의 밝기를 나타내는 L 값의 경우 신선육에서 45.62 을 나타내었으며, 냉·해동에 따른 유의적 변화가 나타나지 않았다. 육색 중 적색도를 나타내는 a 값은 신선육 4.37에서 해동에 따라 유의적으로 증가하는 경향을 나타내었으며, 유수 해동에서 6.29로 가장 높게 나타났다. 황색도를 나타내는 b 값 역시 2.53에서 냉·해동에 의하여 증가하는 경향을 나타냈으나 그 변화폭이 낮게 나타났다. 이러한 결과는 Akamittath 등(25)과 Park 등(8)이 제시한 냉동저장 및 해동에 의하여 적색도가 증가한다는 보고와 차이를 나타내었다. 뿐만 아니라 전체 색변화를 나타내는 $\Delta \mathrm{E}$ 역시 2.28-3.34 사이로 나타나 Park 등(8)의 연구에서 밝힌 냉·해동에 따른 등심육의 색변화 값 4.57-23.67과는 큰 차이를 나타냈다. 이러한 차이는 본 연구에서 개별 포장 한 신선육 동결시 $-80^{\circ} \mathrm{C}$ 를 이용하여 급속냉동하고, 냉동육 의 저장기간 없이 즉시 해동이 이루어져 산소와 접촉에 의한 미오글로빈의 변성 및 품질 손상이 거의 나타나지 않았기 때문으로 판단된다(26).

Table 1. Color hanges in quality of pork sirloins during freezing-thawing

\begin{tabular}{cccccc}
\hline Thawing methods & $\begin{array}{c}\text { Thawing loss } \\
(\%)\end{array}$ & $\mathrm{pH}$ & $\begin{array}{c}\text { VBN } \\
(\mathrm{mg} \%)\end{array}$ & $\begin{array}{c}\text { TBA } \\
(\mathrm{MDA} m \mathrm{mg} / \mathrm{kg})\end{array}$ & $\begin{array}{c}\text { Total aerobic } \\
\text { bacteria (log CFU/g) }\end{array}$ \\
\hline Fresh meat & - & $5.67 \pm 0.0^{1) \mathrm{b} 2)}$ & $5.21 \pm 0.34^{\mathrm{a}}$ & $0.17 \pm 0.02^{\mathrm{ab}}$ & $1.72 \pm 0.32^{\mathrm{a}}$ \\
Tap water & $1.87 \pm 0.07^{\mathrm{b}}$ & $5.66 \pm 0.05^{\mathrm{b}}$ & $6.13 \pm 0.70^{\mathrm{a}}$ & $0.18 \pm 0.04^{\mathrm{a}}$ & $1.55 \pm 0.61^{\mathrm{a}}$ \\
$0 \mathrm{kHz}$ & $2.31 \pm 0.28^{\mathrm{ab}}$ & $5.71 \pm 0.03^{\mathrm{b}}$ & $5.88 \pm 1.03^{\mathrm{a}}$ & $0.22 \pm 0.04^{\mathrm{a}}$ & $1.94 \pm 0.55^{\mathrm{a}}$ \\
$132 \mathrm{kHz}$ & $2.58 \pm 0.21^{\mathrm{a}}$ & $5.69 \pm 0.05^{\mathrm{b}}$ & $6.30 \pm 1.07^{\mathrm{a}}$ & $0.14 \pm 0.05^{\mathrm{b}}$ & $1.89 \pm 0.82^{\mathrm{a}}$ \\
$58 \mathrm{kHz}$ & $3.03 \pm 0.43^{\mathrm{a}}$ & $5.70 \pm 0.04^{\mathrm{b}}$ & $6.14 \pm 0.64^{\mathrm{a}}$ & $0.23 \pm 0.04^{\mathrm{a}}$ & $1.69 \pm 0.37^{\mathrm{a}}$ \\
$1,000 \mathrm{kHz}$ & $2.39 \pm 0.26^{\mathrm{ab}}$ & $5.82 \pm 0.05^{\mathrm{a}}$ & $6.56 \pm 1.07^{\mathrm{a}}$ & $0.23 \pm 0.02^{\mathrm{a}}$ & $1.43 \pm 0.51^{\mathrm{ab}}$ \\
\hline
\end{tabular}

${ }^{1)}$ The values represent mean $\pm \mathrm{SD}(\mathrm{n}=6)$.

${ }^{2)}$ Different superscripts within each column indicate significant differences at $\mathrm{p}<0.05$ by Duncan's multiple range test.

Table 2. Color changes of pork sirloins thawing under ultrasonic thawing systems

\begin{tabular}{ccccc}
\hline $\begin{array}{c}\text { Thawing } \\
\text { methods }\end{array}$ & L-value & a-value & b-value & $\Delta \mathrm{E}$ \\
\hline Fresh meat & $45.62 \pm 2.38^{1 \mathrm{la2} 2}$ & $4.37 \pm 0.74^{\mathrm{d}}$ & $2.53 \pm 0.93^{\mathrm{b}}$ & - \\
Tap water & $45.91 \pm 2.23^{\mathrm{a}}$ & $6.29 \pm 0.51^{\mathrm{a}}$ & $3.62 \pm 1.05^{\mathrm{ab}}$ & $2.93 \pm 0.56^{\mathrm{a}}$ \\
$0 \mathrm{kHz}$ & $45.32 \pm 2.35^{\mathrm{a}}$ & $5.21 \pm 0.83^{\mathrm{bc}}$ & $2.98 \pm 1.16^{\mathrm{b}}$ & $2.28 \pm 0.93^{\mathrm{ab}}$ \\
$132 \mathrm{kHz}$ & $46.71 \pm 3.52^{\mathrm{a}}$ & $5.78 \pm 0.32^{\mathrm{b}}$ & $4.07 \pm 1.01^{\mathrm{a}}$ & $3.34 \pm 1.56^{\mathrm{a}}$ \\
$580 \mathrm{kHz}$ & $45.06 \pm 2.68^{\mathrm{a}}$ & $4.87 \pm 0.23^{\mathrm{d}}$ & $3.03 \pm 1.29^{\mathrm{ab}}$ & $2.57 \pm 0.82^{\mathrm{ab}}$ \\
$1,000 \mathrm{kHz}$ & $45.94 \pm 2.44^{\mathrm{a}}$ & $5.13 \pm 1.03^{\mathrm{cd}}$ & $4.11 \pm 0.66^{\mathrm{a}}$ & $2.56 \pm 1.19^{\mathrm{ab}}$ \\
\hline
\end{tabular}

${ }^{1)}$ The values represent mean $\pm \mathrm{SD}(\mathrm{n}=6)$.

${ }^{2)}$ Different superscripts within each Hunter's values indicate significant differences at $p<0.05$ by Duncan's multiple range test.

색변화

초음파 해동에서 주파수에 따른 동결육의 육색 변화를

\section{물성변화}

초음파 해동에 따른 동결육의 조직감 변화를 Table 3에 나타내었다. 돈육의 경도(hardness)는 냉·해동에 따라 감소 하는 경향을 나타내었으며, 특히 초음파를 이용한 해동에 서 유의적으로 감소하였다. 하지만 변형된 시료가 원래 상 태로 돌아가려는 성질인 탄력성(springiness)은 뚜렷한 변화 가 나타나지 않았으며, 고체 상태의 식품을 삼킬 수 있는 상태로 만드는 성질인 씹힘성(chewiness)에서도 경도와 유 사하게 초음파를 이용한 해동에서 유의적인 감소를 나타낸 반면, 돈육의 조직간 결합력을 나타내는 응집성 (cohesiveness)은 초음파해동에서 증가하는 경향을 나타내 었다. $\mathrm{Kim}$ 등(27)의 연구에서는 해동감량에 의해서 식육 경도가 증가 한다고 밝히고 있으나, Soria와 Villamiel(14)에 따르면 식육에 대한 초음파 처리는 근섬유의 단백질을 이완 시켜 조직의 연화를 돕는다고 밝히고 있다. 빙결정의 성장 
은 드립을 증가시켜 수분함량 감소에 따른 식육의 경도 변화를 가져오지만, 본 연구에서는 급속냉동 후 빠른 해동 으로 인하여 조직손상 및 드립 발생이 최소화되어 품질이 유지 되었을 뿐만 아니라 초음파에 의하여 해동육의 경도가 감소가 낮게 나타난 것으로 판단된다.

Table 3. Changes in texture of pork sirloins thawing under ultrasonic thawing systems

\begin{tabular}{ccccc}
\hline Thawing methods & Hardness $(\mathrm{N})$ & Springiness & Chewiness $(\mathrm{N})$ & Cohesiveness \\
\hline Fresh meat & $1952.01 \pm 333.16^{1 \mathrm{a} 2)}$ & $0.99^{\mathrm{a}}$ & $550.89 \pm 165.43^{\mathrm{a}}$ & $0.29 \pm 0.07^{\mathrm{b}}$ \\
Tap water & $1825.76 \pm 630.30^{\mathrm{a}}$ & $0.99^{\mathrm{a}}$ & $592.37 \pm 291.38^{\mathrm{a}}$ & $0.31 \pm 0.08^{\mathrm{a}}$ \\
$0 \mathrm{khz}$ & $1985.74 \pm 339.57^{\mathrm{a}}$ & $0.99^{\mathrm{a}}$ & $575.38 \pm 156.34^{\mathrm{a}}$ & $0.29 \pm 0.05^{\mathrm{ab}}$ \\
$132 \mathrm{kHz}$ & $1343.39 \pm 440.09^{\mathrm{ab}}$ & $0.99^{\mathrm{a}}$ & $432.13 \pm 205.53^{\mathrm{ab}}$ & $0.32 \pm 0.09^{\mathrm{a}}$ \\
$580 \mathrm{kHz}$ & $1169.53 \pm 590.56^{\mathrm{b}}$ & $0.98^{\mathrm{b}}$ & $345.74 \pm 162.48^{\mathrm{b}}$ & $0.34 \pm 0.14^{\mathrm{a}}$ \\
$1000 \mathrm{kHz}$ & $1509.24 \pm 350.26^{\mathrm{ab}}$ & $0.99^{\mathrm{a}}$ & $479.99 \pm 152.99^{\mathrm{ab}}$ & $0.31 \pm 0.05^{\mathrm{ab}}$ \\
\hline
\end{tabular}

The values represent mean \pm SD $(n=6)$.

${ }^{2)}$ Different superscripts within each values indicate significant differences at $\mathrm{p}<0.05$ by Duncan's multiple range test.

\section{요 약}

본 연구는 초음파를 이용한 해동기의 이용 가능성을 확 인 하고자 수행되었다. 초음파 해동기는 132,580 및 1,000 $\mathrm{kHz}$ 의 공진주파수를 가지는 진동자를 이용하여 각 주파수 로 제작하고 돈육을 일정한 크기로 정형하여 $-80^{\circ} \mathrm{C}$ 에서 냉 동한 후 제작된 해동기를 이용하여 해동 성능을 분석하였 다. 해동속도 비교에서는 초음파를 가하지 않은 접촉식해 동의 경우 일반적으로 가정에서 행해지는 유수식 해동과 유사하게 20 분가량이 소요되었으나, 초음파를 가했을 경우 주파수가 증가할수록 해동시간이 단축되어 $1,000 \mathrm{kHz}$ 에서 는 6분 만에 해동이 완료되었다. 초음파를 이용한 해동 후 품질변화에 대한 분석에서는 재작된 초음파 해동기를 이용 하였을 경우 유수해동에 비하여 드립으로 인한 해동감량이 $0.5 \%$ 가량 증가하였지만 $\mathrm{pH}, \mathrm{VBN}$ 및 TBA 값과 같은 화학 적 특성에서는 차이를 나타내지 않았다. 총 호기성 미생물 에 또한 냉·해동에 따라 큰 차이를 나타내지 않았다. 초음파 해동기를 이용한 해동에서 냉동 전후의 육색을 비교 분석한 결과 명도는 변화는 거의 나타나지 않았지만 유수해동에 비하여 $580 \mathrm{kHz}$ 를 이용한 초음파 해동에서 적색도 및 전체 색변화가 유의적의로 개선되었다. 해동육의 조직감 분석에 서는 초음파 해동에서 경도가 감소하고 저작성이 증가하는 경향을 나타내었다. 이러한 결과를 종합해볼 때 접촉식 초 음파 해동기는 해동시간 단축에 매우 효율적이나 해동육의 품질개선에는 뚜렷한 효과를 나타내지 못하여 경제성을 고려했을 때 성능 개선 및 연육 효과가 나타나는 $580 \mathrm{kHz}$ 해동기의 개선 및 이용방안에 대한 추가적인 연구가 필요
할 것으로 판단된다.

\section{감사의 글}

본 논문은 농촌진흥청 연구사업(세부과제번호: PJ01083601) 의 지원 및 국립농업과학원 박사후 연수과정 지원 사업에 의해 이루어진 것이며, 이에 감사드립니다.

\section{References}

1. Seong PN, Cho SH, Kim JH, Hah KH, Park BY, Lee JM, Kim DH (2009) Meat quality of pork muscles from low-fat cuts. Korean J Food Sci Ani Resour, 29, 364-373

2. Moon YH (2013) Changes in physical properties of ham and loin from low-fat pork cuts during chilling after thawing. J East Asian Soc Dietary Life, 23, 487-495

3. Reied DS (1997) Overview of physical/chemical aspects of freezing quality in frozen food. Springer SBM, New York, USA, p 10-28

4. Obuz E, Dikeman ME (2003) Effects of cooking beef muscles from frozen or thawed ststes on cooking traits and palatability. Meat Sci, 65, 993-997

5. Kiani H, Sun DW (2011) Water crystallization and its importance to freezing of foods: A review. Trends Food Sci Technol, 22, 407-426

6. Hong GP, Park SH, Kim JY, Lee CH, Lee S, Min SG (2005) The effect of thawing rate on the physicochemical properties of frozen ostrich meat. Food Sci Biotechnol, 14, 676-680

7. Virtanen AJ, Goedeken DL, Tong CH (1997) Microwave assisted thawing of model frozen foods using feed-back temperature control and surface cooling. J Food Sci, 62, 150-154

8. Park MH, Kwon JE, Kim SR, Won JH, Ji JY, Hwang IK, Kim MR (2012) Physicochemical and microbiological properties of pork by various thawing methods. J East Asian Soc Dietary Life, 22, 298-304

9. Ko SH, Hong GP, Park SH, Choi MJ, Min SG (2006) Studies on physical properties of pork frozen by various high pressure freezing process. Korean J Food Sci Ani Resour, 26, 464-470

10. Miles CA, Morley MJ, Rendell M (1999) High power ultrasonic thawing of frozen foods. J Food Eng, 39, 151-159

11. Hong GP, Chun JY, Jo YJ, Choi MJ (2014) Effects of 
water or brine immersion thawing combined with ultrasound on quality attributes of frozen pork loin. Korean J Food Sci Anim Resour, 34, 115-121

12. Park JW, Kim JS, Park SH, Choi DS, Choi SR, Kim YH, Lee SJ, Kim HY (2015) Effects of various thawing conditions on quality characteristics of frozen garlic. J East Asian Soc Dietary Life, 25, 893-901

13. Cheng X, Zhang M, Xu B, Adhikari B, Sun J (2015) The principles of ultrasound and its application in freezing related processes of food materials: a review. Ultrason Sonochem, 27, 576-585

14. Soria AC, Villamiel M (2010) Effect of ultrasound on the technological properties and bioactivity of food: a review. Trends Food Sci Technol, 21, 323-331

15. Witte VC, Krause GF, Bailey ME (1970) A new extraction method for determining 2-thiobarbituric acid values of pork and beef during storage. J Food Sci, 35, 582-585

16. Bourne MC (1978) Texture profile analysis. Food Technol, 32, 62-72

17. Huff-Lonergan E, Lonergan SM (2005) Mechanisms of water-holding capacity of meat: The role of postmortem biochemical and structural changes. Meat Sci, 71, 194-204

18. Hamm R (1982) Postmortem changes in muscle with regard to processing of hot-boned beef. Food Technol, 37, 105-115

19. Yu LH, Lee ES, Jeong JY, Paik HD, Choi JH, Kim CJ (2005) Effects of thawing temperature on the physicochemical properties of pre-rigor frozen chicken breast and leg muscles. Meat Sci, 71, 375-382
20. Farouk MM, Wieliczko KJ, Merts I (2004) Ultra-fast freezing and low storage temperatures are not necessary to maintain the functional properties of manufacturing beef. Meat Sci, 66, 171-179

21. Kim YS, Yoo IJ (1994) Effects of sanitary treatment of pork cut surface on shelf-life of chilled pork. J Anim Sci Technol, 36, 403-408

22. Choi YS, Cho SH, Lee SK, Rhee MS, Kim BC (2002) Meat color, TBARS and VBN changes of vacuum packaged Korean pork loins for export during cold storage. Korean J Food Sci Anim Resour, 22, 158-163

23. Turner EW, Payntern WD, Montie EJ, Bessert MW, Struck GM, Olson FC (1954) Use of the 2-thiobarbituric acid reagent to measure rancidity in frozen pork. Food Technol, 8, 326

24. Ockermann HW, Crespo FL, Cahill VR, Plimpton RE, Lrvin KM (1977) Microorganism survival in meat cooked in microwave ovens. Ohio Rept, 62, 38

25. Akamittath JG, Brekke CJ, Schanus EG (1990) Lipid oxidation and color stability in restructured meat systems during frozen storage. J Food Sci, 55, 1513-1517

26. Forrest JC, Aberle ED, Hedrick HB, Judge MD, Merkel RA (1975) Principles of meet science. WH Freeman \& Co Ltd, San Francisco, CA, USA, p 178-185

27. Kim CJ, Lee CH, Lee ES, Ma KJ, Song MS, Cho JK, Kang JO (1998) Studies on physico-chemical characteristics of frozen beef at as influenced by thawing rates. Korean J Food Sci Ani Resour, 18, 142-148 